OPEN ACCESS

Edited by:

Deborah Suchecki,

Federal University of São Paulo, Brazil

Reviewed by: Kazuhiro Takahashi,

Tohoku University, Japan Luigi Michele Pavone, University of Naples Federico II, Italy

Pascal Bonaventure,

Janssen Research and Development,

United States

*Correspondence:

Alain Couvineau

alain.couvineau@inserm.fr Yossan-Var Tan yossan-var.tan@univ-rouen.fr

Specialty section: This article was submitted to Neuroendocrine Science, a section of the journal Frontiers in Endocrinology

Received: 30 July 2019 Accepted: 02 October 2019 Published: 22 October 2019

Citation:

Couvineau A, Voisin T, Nicole P, Gratio V, Abad C and Tan W (2019) Orexins as Novel Therapeutic Targets in Inflammatory and Neurodegenerative Diseases.

Front. Endocrinol. 10:709. doi: 10.3389/fendo.2019.00709

\section{Orexins as Novel Therapeutic Targets in Inflammatory and Neurodegenerative Diseases}

\author{
Alain Couvineau ${ }^{1 *}$, Thierry Voisin $^{1}$, Pascal Nicole ${ }^{1}$, Valérie Gratio ${ }^{1}$, Catalina Abad ${ }^{2}$ and \\ Yossan-Var Tan ${ }^{2 *}$ \\ 1 INSERM UMR1149/Inflammation Research Center (CRI), Team "From Inflammation to Cancer in Digestive Diseases" \\ Labeled by "la Ligue Nationale Contre le Cancer", University of Paris, Paris, France, ${ }^{2}$ University of Rouen Normandy, INSERM \\ U1234 PANTHER, IRIB, Rouen, France
}

Orexins [orexin-A (OXA) and orexin-B (OXB)] are two isoforms of neuropeptides produced by the hypothalamus. The main biological actions of orexins, focused on the central nervous system, are to control the sleep/wake process, appetite and feeding, energy homeostasis, drug addiction, and cognitive processes. These effects are mediated by two G protein-coupled receptor (GPCR) subtypes named OX1R and OX2R. In accordance with the synergic and dynamic relationship between the nervous and immune systems, orexins also have neuroprotective and immuno-regulatory (i.e., anti-inflammatory) properties. The present review gathers recent data demonstrating that orexins may have a therapeutic potential in several pathologies with an immune component including multiple sclerosis, Alzheimer's disease, narcolepsy, obesity, intestinal bowel diseases, septic shock, and cancers.

\footnotetext{
Keywords: orexins, neuropeptides, GPCR, inflammation, neuroprotection, gastroenterology, autoimmune diseases, cancer
}

\section{INTRODUCTION}

The G protein-coupled receptors (GPCR) constitute the largest family of membrane receptors with more than 800 sequences encoded by about $4 \%$ of the human genome (1). GPCRs, which act as molecule sensors on the cell surface, lead to signal transduction by activation and/or inhibition of various intracellular signaling pathways leading to final cellular responses (2). Historically, the first structure determination of a GPCR was that of bovine rhodopsin, solved by Palczewski (3). Nearly 10 years later, the first structure of a human GPCR, the $\beta_{2}$-adrenergic receptor ( $\beta A R$ ), was determined by the group of Rasmussen et al. (4). In 2012, Lefkowitz and Kobilka were awarded with the Nobel Prize in Chemistry "for studies of G-protein-coupled receptors" (5). All GPCRs, also named seven-transmembrane receptor or 7-TM receptors, consist of seven integral $\alpha$-helices transmembrane domains ( $\mathrm{H} 1$ to $\mathrm{H} 7)$ delineating extracellular domains (N-terminal domain and extracellular loops) classically involved in the ligand recognition and intracellular domains (C-terminal domain and intracellular loops) involved in the receptor regulation and signal transduction (6). An eighth $\alpha$-helix (H8), which would be involved in $\mathrm{G} \beta / \gamma$ binding, has been identified through structural studies of GPCRs (3).

The nature of ligands interacting with GPCRs is characterized by a great diversity, including light, ions, amines, lipids, peptides, proteases, small, and large proteins having multiple properties as neurotransmitters, hormones, pheromones, and odors among others (7). The binding of these 
various ligands to GPCRs induces a structural conformational change and leads to the activation of $G$ proteins (transducin, Gs, $G_{i / o}, G_{q / 11}$, and $G_{12 / 13}$ ). Two major signal transduction pathways that have been associated to GPCRs are the cAMP signal pathway through the adenylyl cyclase effector and the phosphatidylinositol signal pathway through the phospholipase $\mathrm{C}$ effector (8). In parallel to its role as a negative regulator of the $\alpha$ subunit, the dissociated $G \beta / \gamma$ has the ability to modulate signaling pathway cascades including, among others, the regulation of ion channels, the inhibition or activation of adenylyl cyclase, the inhibition of the phosphinositide- 3 kinase (PI3K) or the activation of GPCR kinases ( $\beta$ ARK) (9).

GPCRs are classified into 6 groups according to IUPHAR nomenclature: rhodopsin-like (class A), secretin-like (class B), metabotropic glutamate (class C), fungal mating pheromone (class D), cyclic AMP receptors (class E), and frizzled/smoothened (class F). This large family of receptors is widely expressed in eukaryotes from yeast to human, and has an essential role in physiological processes, including homeostasis, hormone secretion, neurotransmission, cell differentiation, immunity regulation, vision, metabolism, muscle contraction, olfaction, pain, and many more (10). Related to the large involvement of GPCRs in human physiopathological conditions, these receptors play a major role in inflammatory diseases either by exacerbating and/or inhibiting inflammation (11). Naturally, our intent is not to describe all actions of the multitude of GPCRs in inflammatory contexts, but to outline some of their implications.

GPCRs are able to act directly on immune cells but also on non-immune cells present in specific tissues and organs (12). Among their major actions, they mediate cell migration, phagocyte activation, degranulation, the production of ROS (reactive oxygen species), vascular endothelial permeability and inflammatory nociception (11). Besides these actions, GPCRs are able to regulate inflammatory gene expression (13). GPCR-ligand binding leads to the modulation of transcription factors involved in inflammatory signaling cascades, such as CREB, ERKs, NFAT, c-Jun, STAT3, and NFKB among others (11). GPCRs have been involved in inflammatory diseases such as rheumatoid arthritis (14), sepsis (15), inflammatory bowel diseases (IBD) (16), pancreatitis (17), multiple sclerosis (18), chronic obstructive pulmonary disease (19), renal inflammation (20), and metabolic syndrome involved in obesity and diabetes (21). In that respect, the crosstalk between the actors of inflammation and GPCRs has led to consider these receptors as very promising targets with potential therapeutic applications in inflammatory pathologies. Among the 800 members of the GPCR family, orexin receptors represent an archetype of a putative target for the treatment of chronic inflammatory diseases (22).

Orexins, also known as hypocretins, comprise two neuropeptides isoforms of 33 and 28 aminoacids, orexin A (OXA/hypocretin-1) and orexin B (OXB/hypocretin-2), respectively (Figure 1). They are encoded by a common precursor polypeptide named prepro-orexin (23). Originally discovered in the hypothalamus in the late nineties, lateral hypothalamic orexin neurons project, and release those peptides widely throughout the central nervous system (CNS) $(24,25)$.
They were initially identified by reverse pharmacology as the endogenous ligands for two orphan GPCR subtypes belonging to the class A family, orexin receptor 1 and 2 (OX1R (Hcrt-1) and OX2R (Hcrt-2), respectively) $(23,25)$ (Figure 1). Signaling pathways that have been associated to orexin receptors are phospholipase A2, C and D, diacylglycerol lipase, $\mathrm{Ca}^{2+}$, and adenylyl cyclase cascades (26).

The major biological action of orexins is the regulation of sleep/wakefulness state $(24,27)$ (Figure 1). Related to this action, one major pathology associated to a deficit of orexin production is narcolepsy with cataplexy, referred to as type 1 narcolepsy (T1N). T1N is characterized by a severe dysregulation of the sleep/wakefulness cycles $(28,29)$. Accordingly, many academic and pharmaceutical laboratories have developed orexin receptortargeting molecules, in particular antagonists, to treat insomnia $(30,31)$. These antagonists have been classified into two types depending on their ability to act on one or both orexin receptors: single orexin-receptor antagonists (SORAs) and dual orexinreceptor antagonists (DORAs). Furthermore, SORAs have been subdivided into two subclasses according to their receptor specificity, SORA1 (such as compound 56) and SORA2 (such as JNJ-42847922), targeting OX1R or OX2R, respectively $(32,33)$. Recently, the DORA molecule suvorexant (MK-4305) has been approved by the U.S. Food \& Drug Administration (FDA) for the treatment of insomnia (34). In addition to their ability to modulate sleep and arousal states, these neuropeptides regulate appetite and feeding, gastrointestinal mobility, energy balance and metabolism, but also play a role in cognitive processes (35-40). Thus, multiple studies have highlighted the therapeutic potential of targeting the orexin system, not only in sleep, cognitive [i.e., Alzheimer's disease (AD)] and metabolic (i.e., obesity) disorders (41-45), but also in ischemic and oxidative stress events $(46,47)$ and in cancer $(48,49)$.

In addition to their actions in the CNS, these neuropeptides also play a role in various peripheral organs where they regulate appetite, feeding, gastrointestinal mobility, energy balance, metabolism, blood pressure, neuroendocrine and reproductive functions (36-41, 50) (Figure 1). In parallel, the expression of orexins in peripheral tissues has been investigated using immunochemistry and RT-PCR strategies which detected mainly the prepro-orexin precursor. Despite a large variability in terms of expression levels, orexins have been detected in adrenal glands (51), adipose tissues (51), kidney (52), colon (53), pancreas (52), and reproductive organs including testis $(54,55)$ and prostate (56). In parallel, orexin receptors are also expressed in peripheral tissues including the gastrointestinal tract, adrenal gland, endocrine pancreas, reproductive system, and adipose tissues $(50,57)$. In these tissues, a paracrine action of orexins is possible. In fact, the circulating level of orexins in blood in healthy individuals is very low [Range of 2 to $45 \mathrm{pM}$, representing 1,000 times less than the $\mathrm{IC}_{50}$ of receptors (58$60)]$. Although the precise source of orexins in disease conditions remains to be elucidated, the abnormal expression of orexin receptors in certain human pathologies has been demonstrated and may lead to new therapeutic targets. In this sense, the ectopic expression of OX1R in human IBD and digestive cancers has been shown, and the administration of exogenous OXA 


\title{
GPCR receptors
}
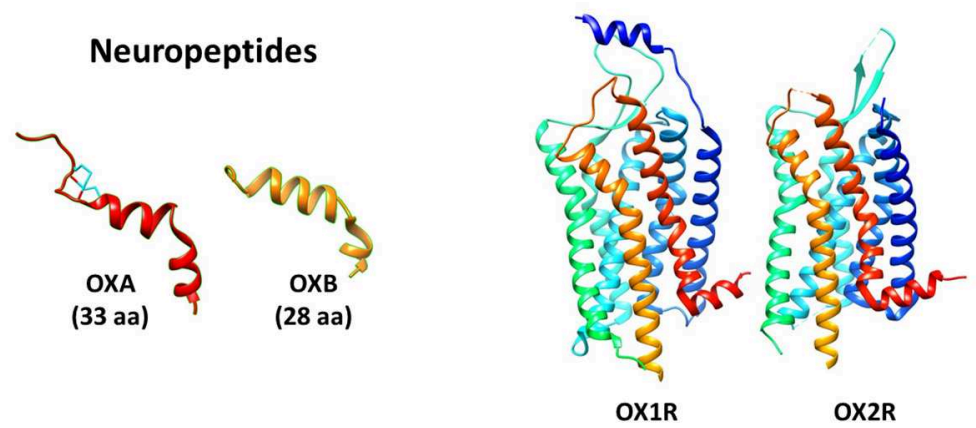

\author{
Major regulatory actions: sleep/wakefulness states \\ drug addiction \\ gastrointestinal motility \\ energy homeostasis \\ endocrine secretions
}

appetite and feeding
cognitive processes
blood pressure
metabolism
reproductive functions

FIGURE 1 | Molecular 3D representation and biological roles of orexins/OXRs system.

led to a protective effect of orexins in animal models of these pathologies (22).

The existence of a bidirectional crosstalk between the nervous and immune systems has been revealed in the last decades. In this context, the present review will attempt to highlight the impact of the administration of exogenous orexins in the central nervous (i.e., neuroprotective properties) and immune (i.e., anti-inflammatory properties) systems in physiological and pathophysiological conditions including neuroinflammation, intestinal bowel diseases and systemic inflammation.

\section{OREXINS AND NEUROINFLAMMATION}

In the CNS, the established relationship between neurons, microglia, and glial cells is highly dynamic and responsive to the diversity of environmental stimuli. For example, in response to injury, infection or disease, the cellular microenvironment of the CNS produces inflammatory mediators including cytokines, chemokines, adhesion molecules, prostaglandins, and free radicals. Those mediators stimulate the recruitment of additional immune cells as well as the activity of astrocytes and microglia. Particularly, in the healthy brain, microglia, resident macrophage-type immune cells of the CNS that share many characteristics with macrophages, are vital to preserve neuronal health (i.e., to promote formation and elimination of synapses) by maintaining a friendly CNS microenvironment. Indeed, microglial cells are capable of adopting appropriate phenotypic responses (i.e., inflammatory and activated vs. anti-inflammatory and resting) according to the type of stimuli. This immune reactivity of the CNS is beneficial and has to be under tight control to efficiently recover physiological homeostasis; however, long-term and dysregulated neuroinflammation, which is generally accompanied by a chronic inflammatory phenotype of microglia, can trigger deleterious effects on the CNS (i.e., subsequent and progressive neuronal loss). Thus, neuroinflammation is a key mechanism contributing to the progression and exacerbation of neurodegenerative and/or inflammatory diseases of the nervous system.

This concept gained even more credence with the discovery of neuropeptides exerting both neuroprotective and immunomodulatory actions, and becoming an emerging group of biological agents with a great potential for the treatment of immune-mediated CNS disorders such as narcolepsy, metabolic disorders, Alzheimer's disease, and multiple sclerosis. One potential candidate is the orexin system. Indeed, an increasing amount of evidence suggest a novel involvement of the orexin/receptor system in the immune and nervous systems. Particularly, as it will be discussed below, one of the two orexins, OXA, exhibits via activation of orexin receptors, neuroprotective, and immuno-regulatory actions, and thus its administration may be beneficial in the aforementioned diseases.

\section{OREXINS NEUROPROTECTIVE ACTIONS}

Recent studies have reported that the hypothalamic neuropeptide OXA (OXA, hypocretin 1) may exert an important role in neuroprotection, in part by reducing apoptosis and inflammation (47, 61, 62). Hence, using orexin/ataxin-3 (O/A3) mice, a transgenic mouse model of neurodegeneration, orexin loss has been linked to neurodegeneration, memory and cognitive deficits, and neuroinflammation (63). Supporting a role for endogenous orexin in neurodegenerative/inflammatory brain pathology, orexin expression was found to be elevated in lesioned CNS areas in murine controlled cortical impact (CCI) and transient common carotid artery occlusion (tCCAO), models of 
traumatic brain injury and cerebral ischemia, respectively (64, $65)$. In these studies, the cellular localization of orexin receptors was further investigated by immunofluorescence. Although orexin receptors expression is known to be neuronal in healthy brain tissue, expression by glial cells was also reported in these models. For example, OX1R receptor was found to be upregulated in microglia after CCI (64). Moreover, astrocytes and oligodendrocytes were found to express OX1R after tCCAO (65). Although evidence in human pathology is missing, these studies may suggest a potential action of orexin not only on neurons, but also on glial cells.

Data indicate that orexin-induced neuroprotection could rely upon microglial modulation $(62,66)$. Microglia behave like a sentry capable of efficiently react to endogenous signaling in order to initiate proper neuroinflammatory responses through dynamic transitioning between neurotoxic pro-inflammatory (M1) and neuroprotective (M2) phenotypes. For example, following cerebral ischemic events, microglia can adopt two phenotypes: first an activated neuroprotective M2 phenotype together with the reduction of oxygen levels, and then switch to a pro-inflammatory M1 phenotype, provoking cell death (67). While inflammation is a required normal immune response, chronic M1 pro-inflammatory activation can be detrimental and contributes to subsequent neuronal dysfunction and damage (68). In this context, numerous evidences shed the light on the orexins/receptors system involvement. Indeed, in vivo, OXA exhibited potent neuroprotective actions in several models of rodent focal cerebral ischemia, reducing infarct size (46, $62,69)$. This set of data implies a mechanism driven by microglia $(46,62,69)$.

Several in vitro studies have demonstrated that OXA promotes both neuronal survival and neuronal protection from death caused by oxidative and hypoxic stress. For example, orexins A and $\mathrm{B}$ were capable of efficiently protecting primary rat cortical neurons against cobalt-induced oxidative stress (70). Using SH-SY5Y human neuroblastoma cell line, an in vitro cellular model of dopaminergic neurons in Parkinson's disease, other investigators have shown that OXA elicited neuroprotective actions (i.e., anti-apoptotic and antioxidant effects which are mediated by the PKC and PI3K signaling pathways) against $\mathrm{MPP}(+)$ and 6-OHDA-induced neurotoxicity (71-73). These in vitro results might be relevant in light of MS pathogenesis. Indeed, accumulating evidence suggests that oxidative stress, at least in part, contributes to MS pathophysiological processes such as demyelination, axonal damage and neuronal death. In another study, a microarray analysis of neuronal differentiated SH-SY5Y cells treated with OXA revealed the upregulation of somatostatin receptors, vasoactive intestinal peptide (VIP), endothelin-1 (EDN1), and members of the NF-кB pathway, all of which contribute to neuroprotection (74).

\section{Orexins Immuno-Regulatory Properties}

In addition to its effects in the nervous system, several studies have shown that OXA can act in vivo as an anti-inflammatory neuropeptide, further supporting its therapeutic potential in neurodegenerative and/or inflammatory disorders. In a rat model of ischemia reperfusion-induced gastric damage, the infusion of OXA: (1) dramatically reduced gastric damage by diminishing the production of reactive oxygen species (ROS) and (2) reduced myeloperoxidase activity in the gastric tissue, suggesting a decrease in polymorphonuclear infiltration and/or activity (75). Later on, using a murine focal cerebral ischemia model, another group demonstrated that the extent of brain lesions were attenuated by the endogenous orexin system, an effect associated with reduced inflammation (i.e., decrease of IL-6 and TNF $\alpha$ levels) (76). More recently, peripheral administration of orexin reduced the levels of proinflammatory mediators (i.e., cytokines and chemokines) and improved the survival of mice in the model of lipopolysaccharide (LPS)induced endotoxin shock (77). In addition, exposure to LPS down-regulated orexin signaling, supporting the contribution of orexins during an inflammatory event (78). Interestingly, this study demonstrated that peripherally administered OXA was able to cross the blood brain barrier (BBB) under endotoxin shock conditions and acted directly to reduce inflammation in the CNS. This evidence strongly suggests that the orexinergic system can exert its beneficial immuno-regulatory functions not only in inflammatory, but also in immune-driven neurodegenerative diseases.

Despite the scarcity of data regarding the expression of orexin receptors in immune cells, we found that OX1R and OX2R receptors are expressed in murine central and peripheral immune cell tissues, and particularly in sorted $\mathrm{T}\left(\mathrm{CD} 4^{+}\right.$and $\left.\mathrm{CD}^{+}\right)$ and myeloid $\left(\mathrm{CD} 11 \mathrm{~b}^{+}\right)$cells (79). We have also described the expression of OX1R in murine colonic lamina propria immune cells (80).

The cellular and molecular mechanisms by which OXA exerts its anti-inflammatory actions in those models have been poorly investigated, with mostly in vitro studies performed. Indeed a direct effect of orexin signaling on microglial cell lines has been shown $(62,66)$. In normal circumstances, the potent proinflammatory agonist lipopolysaccharide (LPS) increases TNF$\alpha$ production in microglial cell line $\mathrm{BV}-2$ as well as $\mathrm{OX} 1 \mathrm{R}$ expression. Interestingly, Xiong et al. reported that a pretreatment with OXA of the BV-2 cells prior to LPS exposure led to a reduction of TNF- $\alpha$ (62). Although this might suggest an action on innate immune cell mechanisms, the limitation of this work is its in vitro nature. Further studies would be required to demonstrate the relevance of this data as a mechanism for orexin immunoregulatory properties in vivo.

Overall, these recent findings suggest a therapeutic potential of OXA in inflammatory diseases of the CNS.

\section{OREXINS IN DISEASE}

\section{Narcolepsy}

Type 1 narcolepsy $(\mathrm{T} 1 \mathrm{~N})$ is a rare but severe chronic neurological sleep disorder (81). Its main symptoms are an excessive daytime sleepiness, cataplexy (sudden loss of muscle tone), fragmented night time sleep with episodes of sleep paralysis and hallucinations (81). T1N is triggered by a selective and almost complete destruction of orexinergic neurons in the lateral hypothalamus $(82,83)$. Numerous evidence obtained from risk factor studies (i.e., genetic and environmental) and serologic 
data, suggest that $\mathrm{T} 1 \mathrm{~N}$ pathogenesis is an autoimmune-based process. A high association of the disease incidence has been found with certain human leukocyte antigen (HLA) class I alleles (i.e., HLA-DQB1*06:02 allele) (84-86), with polymorphisms in the $\alpha$ chain locus of the T-cell receptor (TCR) $(87,88)$, with the presence of autoantibodies against different CNS antigenic targets identified in the serum and cerebrospinal fluid (CSF) (8991 ) and with the vaccination campaigns (i.e., Pandemrix vaccine) against pandemic H1N1 influenza virus (92-94). Even if it has to be confirmed, molecular mimicry has been proposed as a pathophysiological mechanism of the disease $(91,95)$.

In order to study the autoimmune mechanisms involved in the development of narcolepsy and particularly to discover the effector immune cells responsible for the selective orexinsecreting neuron destruction, a novel mouse model of narcolepsy has been generated (96). Mice were designed to express a "neo-self-antigen" [i.e., hemagglutinin (HA)] specifically in hypothalamic orexin-expressing neurons (named Orex-HA). To induce the disease, they were then adoptively transferred with effector neo-self-antigen-specific $\mathrm{T}$ cells either $\mathrm{CD}^{+}{ }^{+} \mathrm{Th} 1$ or cytotoxic $\mathrm{CD}^{+}$(CTLs). Both HA-specific $\mathrm{T}$ cells were able to infiltrate the hypothalamus and cause local inflammation. However, only CTLs were capable of leading to a narcolepticlike phenotype mimicking human $\mathrm{T} 1 \mathrm{~N}$ clinical manifestations such as cataplexy and sleep attacks. The latter phenotype was accompanied with a selective and drastic destruction of orexin ${ }^{+}$neurons due to a direct and antigen-dependent CTL-mediated cytotoxicity. This work thus emphasizes that narcolepsy pathogenesis is strongly mediated by the immune system (i.e., CTLs play a central effector role) and suggests that novel therapeutic strategies including OXA should trigger the protection of orexin-secreting neurons.

Studies using orexin receptor transgenic mice have suggested a major role for OX2R in narcolepsy. Indeed, narcolepsy in dogs has been associated with a deficiency of the OX2R (29), and narcolepsy-cataplexy symptoms have been observed in OX2Rand not in OX1R- deficient mice $(97,98)$. Moreover, wakefulness is inhibited only by OX2R and dual orexin receptor antagonists, but not by selective OX1R antagonists (99). Recently, it was shown that peripheral administration of a potent non-peptidic OX2R agonist, YNT-185, significantly ameliorated narcolepsy symptoms in mice (100). This study supports a therapeutic use for orexin receptor agonists (in particular OX2R agonists) as a therapy in narcolepsy.

\section{High Fat Diet (HFD)-Induced Obesity}

Given the fact that: (1) the orexin system efficiently controls appetite and feeding as well as the energy balance and metabolism and (2) OXA exhibits potent neuroprotective function, for example by attenuating oxidative stress-induced cell death, another team was interested in deciphering how the dynamic orexin-microglia dialogue might interfere with brain health to induce obesity through high fat diet in saturated fatty acids (SFA) [i.e., palmitic acid (PA, C16:0)] exposure (66). Chronic dietary intake enriched in PA contributes to hypothalamic neurodegeneration (i.e., neuronal cell death and apoptosis) in part through earlier onset of increased oxidative stress, overproduction of ROS, insulin resistance, and hippocampal neuroinflammation (i.e., release of circulating proinflammatory cytokines from microglial cells) (63, 101-105). Additionally, HFD-induced ROS leads to an impairment in hypothalamic gene expression profiles linked to obesity pathogenesis including downregulation of the neuronal anti-apoptotic protein $\mathrm{B}$ cell lymphoma 2 (Bcl-2), but upregulation of the pro-apoptotic protein B cell lymphoma 2 associated X protein (Bax) $(106,107)$.

Using the immortalized murine BV-2 microglial cell line, authors have shown that PA treatment: (1) increases OX1R gene expression but not OX2R and (2) causes the BV-2 cell line to shift toward a pro-inflammatory M1 state (66). In parallel, other teams demonstrated that PA diet activates microglia to an $\mathrm{M} 1$ phenotype, resulting in the release of pro-inflammatory cytokines such as TNF- $\alpha$ and IL-6, under either a NFKB- or a toll like receptor 4 (TLR-4)-dependent pathway $(66,103,108,109)$. Further, microglial activation by SFA via TLR- 4 contributes to neuronal cell death (108). However, OXA efficiently blocked the harmful effects of PA. Indeed, OXA is capable of promoting a neuroprotective anti-inflammatory M2-like microglial phenotype at the expense of the PA-induced neurotoxic proinflammatory microglial M1 phenotype. This was characterized by increased expression of the M2 microglial marker arginase-1, while inhibiting the production of pro-inflammatory $\mathrm{TNF} \alpha$, IL-6 and inducible nitric oxide synthase (iNOS) mediators (66). In addition, using an immortalized murine hypothalamic neuronal cell line (named as mHypoA-1/2), Duffy et al. showed that OXA protects hypothalamic neurons against PA-induced hypothalamic microglial dysregulation (110). This beneficial effect was accompanied with: (1) diminished caspase-3/7 apoptosis, stabilization of Bcl-2 gene expression, and subsequent decrease of $\mathrm{Bax} / \mathrm{Bcl}-2$ gene expression ratio, (2) inhibition of ROS production, and (3) a reversion of PA-induced changes in intracellular metabolism, basal/maximum respiration, ATP production and reserve capacity (110). These data support the concept that OXA can efficiently block the actions of $\mathrm{PA}$ and may act as a potent immuno-regulator of M1/M2 phenotype microglia, reducing pro-inflammatory cytokines and increasing anti-inflammatory cytokines to promote a beneficial neuronal microenvironment.

\section{Alzheimer's Disease (AD)}

Alzheimer's disease is primarily characterized by the loss of pyramidal neurons and synapses in the cerebral cortex as well as in some subcortical regions such as the hippocampus. This event results in general in brain atrophy as well as expanded ventricular volume. Alongside intracellular aggregates of hyper phosphorylated tau proteins and extracellular deposits of amyloid- $\beta(A \beta)$ aggregates (111), both clinical and preclinical studies have provided recent data clearly determining that $\mathrm{AD}$ is a multistep disorder in which chronic and uncontrolled neuroinflammatory processes play an important role for its development. Initially, to preserve healthy brain function, inflammatory responses against $A \beta$ deposits from microglia and astrocytes coordinate efficient phagocytic removal and enzymatic breakdown of amyloid peptides, respectively. However, AD patients present excessive tau protein and $A \beta$ deposition 
that overcomes physiological clearance, resulting in continued microglial stimulation. The latter significantly leads to an overproduction of pro-inflammatory cytokines which foster dysregulated neurodegeneration (i.e., death of otherwise healthy proximal neurons) in the brain microenvironment $(112,113)$. In addition, cellular debris and damage-associated molecular patterns from these degenerating neurons can further enhance the stimulation of microglia and the production of inflammatory mediators. It has been shown that diet factors, such as PA, potentiate the risk of not only developing obesity but also cognitive disorders such as $\mathrm{AD}$. In this regard, as mentioned before, several teams have demonstrated the beneficial effects of OXA by antagonizing the proinflammatory actions of PA diet $(62,63,66,110)$. The pathogenic role of excessive inflammation in $\mathrm{AD}$ suggests that an antiinflammatory treatment may exert beneficial actions in the disease.

Sleep is critical for physiological brain function allowing the clearance of neurotoxic waste products such as $\mathrm{A} \beta$ (114) and stimulates synapse formation and maintenance during the learning process $(115,116)$. In contrast, sleep deprivation leads to inflammation, reactive glia response, reduced $\mathrm{A} \beta$ clearance ability $(114,117)$ and subsequently strongly increases its levels in the hippocampus and cortex (41) in AD-relevant mouse models. In this sense, increasing evidence in mice and in human suggests that sleep disruption may exacerbate the progression of Alzheimer's neuropathology and cognitive deterioration including memory (118-121). In this context, Duncan et al. tested whether a chronic administration of a dual orexin receptor antagonist (DORA) would favor sleep enhancement and attenuate the development of $\mathrm{AD}$ by reducing neuropathology, neuroinflammation, and cognitive deficits. For this purpose, an $\mathrm{AD}$-relevant mouse preclinical model (i.e., 5XFAD mice) which exhibits AD-like features (i.e., sleep disruptions, neuropathology, neuroinflammation, and cognitive deficits including spatial memory) was chosen for the study. In 5XFAD mice, DORA significantly increased light-phase sleep and restored natural sleep patterns (122). Nevertheless, it did not impact neuropathological and neuroinflammatory features of the disease with similar $A \beta$ levels and plaque density in comparison with untreated-DORA mice. 5XFAD mice did not exhibit cognitive deficits in this study. Therefore, the authors could not evaluate whether or not DORA-induced increased sleep improved cognitive functions (122). This set of findings suggests that OXA antagonist analogs (DORA) may be used to improve sleep pattern in $\mathrm{AD}$ patients, but its impact on neuroinflammation remains unknown.

Thus, we might speculate that whereas OXA agonists might decrease inflammation (i.e., in the case of high fat diet associated pathology) and potentially $\mathrm{AD}$, antagonist molecules might be beneficial by improving sleep patterns in AD patients with sleep deficits. Further research is needed to determine the best orexinbased therapy in $\mathrm{AD}$.

\section{Multiple Sclerosis (MS)}

Multiple sclerosis is a chronic demyelinating disease of the central nervous system. MS is initially characterized by episodes of acute symptoms, followed by partial or complete recovery (relapsing-remitting MS), until remissions no longer occur and disability continuously progresses (progressive MS). Despite its complex pathogenesis, it is established that chronic inflammation in the spinal cord and brain is driven by a Th1/Th17 autoimmune component of the disease. This is characterized by exacerbated neurodegeneration and failure of central nervous system repair mechanisms. Thus, most of MS therapies are immunomodulatory. However, current treatments are only partially effective at the earliest phases of the pathology slowing its progression of disability and also reducing its severity and incidence of exacerbations with somehow important side effects, and have no major impact on its progressive phase (123-125). In addition to inflammation, axonal and neuronal pathologies are central components during MS.

The aforementioned evidences suggest that OXA may present potent therapeutic properties for MS by acting on both inflammatory and neurodegenerative components of the disease. An upregulation of hypothalamic orexin receptor mRNA expression has been described upon experimental autoimmune encephalomyelitis (EAE, a widely used MS mouse model) (126). The same team has shown that intracerebroventricular (ICV) delivery of OXA starting before disease onset, attenuated the clinical score of EAE (127). Nevertheless, this brief study did not address whether or not OXA was able to dampen key components in MS pathogenesis, such as Th1 and Th17 encephalitogenic responses and neurodegeneration. Compared to ICV administration, peripheral administration of OXA might be more interesting from a therapeutic standpoint. Whereas, IP-delivered OXA might easily reach immune organs, a desired local action at the level of the CNS, notably to provide neuroprotection, would require that this neuropeptide crosses the BBB. There is not much information in this sense, but one study demonstrated that intravenously delivered OXA was capable of crossing the BBB from the blood by simple diffusion (128). Furthermore, as mentioned before, peripherally (IP) administered OXA was capable of crossing the $\mathrm{BBB}$ and reach the CNS in a study of LPSinduced systemic inflammation (77). This suggests that OXA administered peripherally might act both at CNS and peripheral levels. In order to respond to these issues in MS mouse models, we investigated the curative potential of peripheral OXA administration in the clinical development of ongoing established chronic myelin oligodendrocyte glycoprotein 3555 (MOG $35-55$ )-induced EAE (a mouse model for progressive MS). Moreover, we studied the impact of this treatment on inflammatory and neurodegeneration processes that underlie the pathogenesis of EAE. We found that an intraperitoneal OXA administration to mice undergoing established chronic MOG $35-55$-induced EAE had a striking curative effect by alleviating the clinical symptoms and histopathological features of the disease. This was associated to a global reduction of the inflammatory response in the CNS, including a decrease of immune cell infiltration (i.e., $\mathrm{CD} 4^{+} \mathrm{T}$ cells) and the expression of immune cell mediators (chemokines such as MCP-1/CCL2 and IP-10/CXCL10, and cytokines such as IFN- $\gamma$, IL-17, TNF- $\alpha$, IL10 , and TGF $\beta$ ) (79). In parallel, OXA diminished demyelination, astrogliosis and microglial activation. The immunomodulatory 
effects of OXA were not observed in the periphery, since OXA failed to inhibit in vitro draining lymph node cell responses to $\mathrm{MOG}_{35-55}$ (proliferation and Th1/Th17 cytokine production) (79). Overall, this set of results provided the proof-of-concept that peripheral administration with OXA may be beneficial in MS.

\section{IBD}

Intestinal bowel diseases (IBD) encompassing Crohn's disease (CD) and ulcerative colitis (UC) are characterized by chronic inflammation of the intestinal mucosa (129). UC is a crippling disease characterized by relapsing-remitting cycles affecting exclusively the mucosa of the colon and rectum following a distal to proximal inflammatory gradient (130). This inflammatory disease was described during the acute phase by the change of mucosal structure resulting of an alteration of mucus-secreting goblet cells, crypt distortion, and crypt abscesses induced by an immune cell infiltration trough the epithelium (130). In this respect, the presence of these lesions might, at least in the longer term, evolve toward dysplasia and colorectal cancer (CRC) (131). The major symptoms are abdominal pain, persistent diarrhea including bloody stools, weight loss, and large fatigue (130). The incidence of this pathology is about 300 per 100,000 in the USA with a general prevalence of IBD of $0.3 \%$ in North America, Oceania and Europe (132). At date, the exact cause of UC remains mainly unknown. UC is a multiple pathogenic disease involving various factors, including genetic susceptibility, environmental impact, dysbiosis, dysregulation of innate and adaptive immune response, inflammasome signaling pathway, regulatory RNAs and endoplasmic reticulum (ER) cellular stress (133).

Currently, the treatment of UC is dependent on the severity of disease. The first line of treatment involves anti-inflammatory drugs, including 5-aminosalicylates and corticosteroids (134). The use of immune system suppressors such as azathioprine, methotrexate, cyclosporine, anti-TNF $\alpha$ (Infliximab) and antiintegrin/ $\alpha 4 \beta 7$ (Vedolizumab) is also prescribed alone or in combination (134). Unfortunately, the failure of medication, a significant degradation in the quality of life and/or severe flareups including acute severe colitis, perforation, uncontrollable bleeding and risk of cancer leads to perform surgery consisting of total colectomy (134). In this context, the identification of new targets represents a major goal in the treatment of this pathology. GPCRs may constitute these innovative new targets. Indeed, most of those receptors are potential targets in colitis such as chemokine receptors (135), cannabinoid receptors (136), histamine receptors (137), and neuropeptide receptors (138). Recently, it was shown that OX1R was expressed in inflamed mucosa from patients having UC (80), but not in normal mucosa (139). It should be emphasized that an UC rat model reproducing chronic mucosal inflammation by injection of adjuvant mixture containing proteins from UC patients, revealed an upregulation of OXA in colon (140). Moreover, an epidemiologic analysis from narcoleptic patients indicated a higher prevalence of immunopathological diseases, including among others Crohn's disease and ulcerative colitis (141). In the classical DSS-induced acute colitis mouse model, OX1R was found to be highly expressed in inflamed colon mucosa whereas the receptor was not expressed in normal mucosa (80). Three intraperitoneal injections of OxA by week in this animal model resulted in an anti-inflammatory effect characterized by the restoration of the intestinal barrier and the inhibition of TNF $\alpha$, IL- $1 \alpha$, IL-1 $\beta$, IL-6, IFN $\gamma$, IL-17 cytokines and the MCP-1 chemokine in the colon mucosa (80). More recently, Tunisi et al. have demonstrated that OxA prevents the disruption of the intestinal barrier induced by LPS in Caco-2 cells and in vivo (142). The use of a genetically modified murine model where the IL-10 and NAPDH Oxydase 1 (NOX1) genes were invalidated, which mimics the chronic phase of human UC (80), has demonstrated the same antiinflammatory effect of OXA. Moreover, these OXA-induced antiinflammatory effects were specific because they were reverted by: (1) the SORA molecule SB-408124 which is an OX1R specific antagonist (80) and (2) the use of an OX1R ${ }^{-/-}$mouse model in which UC was induced by DSS (80). The anti-inflammatory effect of OXA was mainly mediated by the activation of intracellular calcium releasing signaling pathway and by the inhibition of the NFKB activation (Figure 2) (80). In this study, OX1R was expressed by $\mathrm{T}$ lymphocytes and its activation by OXA led to an inhibition of pro-inflammatory cytokines (80).

\section{Digestive Cancers}

Considering that chronic inflammation encompassing IBD, pancreatitis, hepatic fibrosis and metabolic syndrome constitute a high-risk factor to develop cancers (131), the role of orexins in inflammation represents a major question. In 2011, our group had demonstrated that OX1R but not OX2R was highly expressed in colon cancer cell lines and colorectal tumors from patients (139). It should be noted that: (1) no detection of prepro-orexin was observed in normal and tumoral colonic epithelia (139) and (2) OX1R was not detected in normal colon epithelium (22). Orexins treatment of digestive cancer cell lines derived from colon, pancreas and liver cancers (22, $139,143)$ induced a strong cell death by apoptosis. The orexininduced apoptosis was mediated by the phosphorylation of two tyrosine-based motifs (ITIM) present in the receptor sequence. This triggered successive signaling events (Figure 2), such as: the recruitment of the phosphotyrosine phosphatase SHP2, the phosphorylation of the p38 mitogen/stress-activated protein kinase and the translocation of the proapoptotic protein Bax in the mitochondria, leading to apoptosome formation and caspase (3 and 7 ) activation $(144,145)$. In a preclinical model, where cancer cells lines derived from colon, pancreas, liver and prostate cancers were sub-cutaneously xenografted, OXA treatment induced a strong reduction of tumor volume (22). This antitumoral effect of OXA was also observed in the patient-derived xenograft model (143). The expression of OX1R in digestive cancers had occurred at an early stage since the dysplastic cells present in colon polyps or pancreatic intraepithelial neoplasia (PanIN) lesions highly expressed OX1R $(22,143)$.

\section{Septic Shock}

Sepsis is a systemic infection syndrome representing one of the most important causes of admission in the intensive care unit and potentially life threatening (146). Septic shock, which is associated to organ(s) dysfunction, is the culmination of sepsis through a continuum between infection to severe sepsis (147). It should be noted that the difference between sepsis 


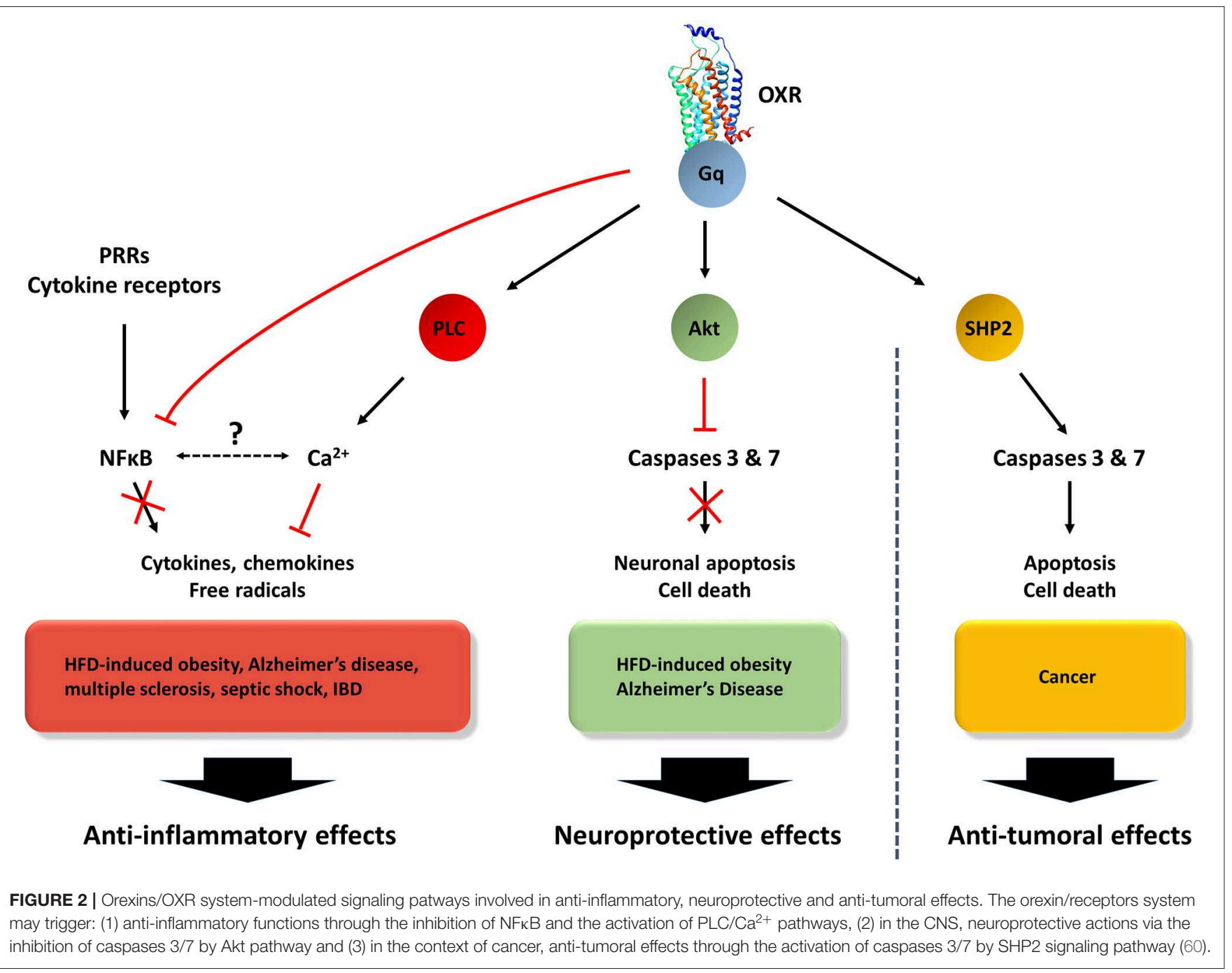

and the systemic inflammatory syndrome (SIRS) is only related to the presence of one identifiable focus of infection in sepsis (147). Clinical signs associated with septic shock encompass fever, hypotension, tachycardia, oliguria, respiratory distress, skin marbling, confused thinking, and they can evolve to coma. Except for the intensive care associated with organ failure, including heart, kidney, respiratory tract, liver and brain, the treatment of septic shock consists of intravenous injection of empiric antibiotics, vasopressor medications, insulin and corticosteroids (148).

Although the pathological mechanisms involved in organ failure associated to septic shock are not completely understood, some candidate factors involved have been identified. An exacerbated secretion of inflammatory cytokines such as TNF $\alpha$, IL-6, IL-1 $\beta$, and MCP-1 has been described in sepsis (147). Associated with this cytokine storm, NFkB, which plays a central role in the induction of transcription pro-inflammatory genes, has been involved in septic shock (147). Indeed, the use of NFKB inhibitors as pyrrolidine dithiocarbamate and parthenolide in lipopolysaccharide (LPS)-induced septic shock murine models improved organ failure and hypotension (149). Cellular apoptosis process also plays a prominent role in septic shock. For example, $\mathrm{T}$ and $\mathrm{B}$ cell apoptosis has been reported in septic shock patients, leading to immunosuppression (147). Apoptosis of intestinal and lung epithelial cells has been also observed in autopsied patients (150). In addition, LPS, which is one of the major component of gram negative bacteria walls, is involved in septic shock. LPS interacts with the complex toll-like receptor 4 (TLR4)/myeloid differentiation factor 2 (MD-2). TLR4 is expressed in various cells such as macrophages, dendritic cells, adipocytes, enterocytes and mucosal cells, in which LPS induces cytokine and interferon secretion via NFKB activation (151).

Several GPCRs and their ligands have been involved in septic shock and/or in its treatment, including chemokine receptors (i.e., CCR2, CX3CR1, and CXCR1), neuropeptides (i.e., VIP, neuropeptide Y, ocytocin, vasopressin, neurotensin, orexins, substance $\mathrm{P}$, and apelin), proteases [i.e., thrombin (PAR1 and PAR2)], lipid derivatives [i.e., N-arachidonylglycine (GPR18)] and amines (i.e., catecholamines, dopamine histamine, melatonin) (152-156). 


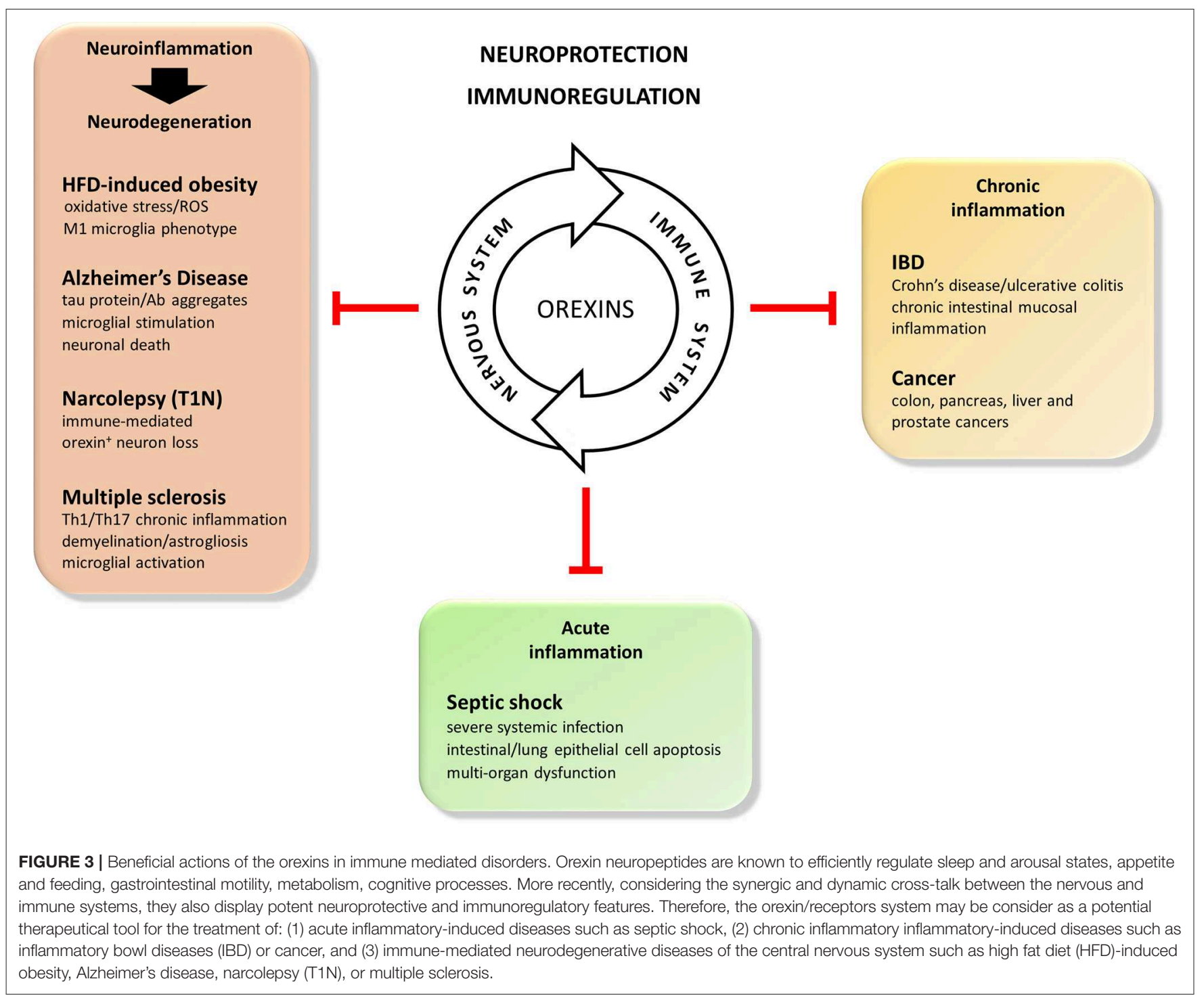

The standard animal model used to study the role of GPCRs, particularly orexin receptors, in systemic inflammatory responses in the absence of infection, has been the endotoxemia model induced by LPS injection (157). In parallel, other models using either live bacteria administration or cecal ligation and puncture (CLP) which exposes the cecal content rich in bacteria into the peritoneal cavity have been used (157). In the early 2010s, Deutschman et al. using the CPL mouse model had demonstrated that the orexinergic activity was strongly reduced (158). This inhibition was associated with a reduction of respiratory, heart, temperature and arousal rates (158). Conversely, the intravenous injection of OXA reverted these clinical signs. Other reports indicate that LPS or TNF $\alpha$ (a major cytokine involved in septic shock) were also able to suppress orexin neuronal activity (159). More recently, the use of orexin-neuron ablated mouse model (OX/ataxin-3 transgenic mouse model) injected with LPS revealed a high mortality rate as compared to wild type mice (160). Moreover, the injection of LPS in wild type mice reduced OXA tissue content compared to untreated mice (160).
Yanagisawa's group had clearly shown that the subcutaneous diffusion of OXA using an osmotic pump in LPS-induced endotoxin shock mice improve the survival of these mice (77). OXA ameliorated hypothermia and bradycardia associated to LPS-induced endotoxin shock, and reduced the secretion of TNF $\alpha$, CCL3, IFN $\gamma$, IL-17, and IL-6 (77).

\section{CONCLUSIONS}

Recent literature suggest that the orexin/receptor system can be added to the list of nervous system mediators exhibiting immunoregulatory properties. Overall, the in vivo and in vitro studies gathered here strongly indicate that, in addition to their conventional actions (Figure 1), orexins are neuropeptides with important neuroprotective and antiinflammatory properties. This may expand their current interest as therapeutic agents from sleep disorders to neurodegenerative disorders with/without a neuroinflammatory component (i.e., HFD-induced obesity, Alzheimer's disease, narcolepsy and 
multiple sclerosis), acute inflammatory diseases (i.e., septic shock) and chronic inflammatory diseases (i.e., inflammatory bowel diseases and associated cancers) (Figure 3). Based on the data gathered in this review, Figure 2 summarizes potential molecular mechanisms leading to these effects.

\section{AUTHOR CONTRIBUTIONS}

AC, TV, PN, VG, CA, and YVT have actively participated in the writing of this manuscript.

\section{REFERENCES}

1. Bjarnadottir TK, Gloriam DE, Hellstrand SH, Kristiansson H, Fredriksson $\mathrm{R}$, Schioth HB. Comprehensive repertoire and phylogenetic analysis of the G protein-coupled receptors in human and mouse. Genomics. (2006) 88:263-73. doi: 10.1016/j.ygeno.2006.04.001

2. Rajagopal S, Rajagopal K, Lefkowitz RJ. Teaching old receptors new tricks: biasing seven-transmembrane receptors. Nat Rev Drug Discov. (2010) 9:373-86. doi: 10.1038/nrd3024

3. Palczewski K, Kumasaka T, Hori T, Behnke CA, Motoshima H, Fox BA, Le Trong I, et al. Crystal structure of rhodopsin: a G proteincoupled receptor. Science. (2000) 289:739-45. doi: 10.1126/science.289. 5480.739

4. Rasmussen SG, DeVree BT, Zou Y, Kruse AC, Chung KY, Kobilka TS, et al. Crystal structure of the beta2 adrenergic receptor-Gs protein complex. Nature. (2011) 477:549-55. doi: 10.1038/nature10361

5. Kenakin T. Making receptors a reality: the 2012 Nobel Prize in Chemistry. Trends Pharmacol Sci. (2013) 34:2-5. doi: 10.1016/j.tips.2012.11.003

6. Couvineau A, Ceraudo E, Tan YV, Nicole P, Laburthe M. The VPAC1 receptor: structure and function of a class B GPCR prototype. Front Endocrinol. (2012) 3:139. doi: 10.3389/fendo.2012.00139

7. Edward Zhou X, Melcher K, Eric Xu H. Structural biology of G proteincoupled receptor signaling complexes. Protein Sci. (2019) 28:487-501. doi: $10.1002 /$ pro. 3526

8. Weis WI, Kobilka BK. The molecular basis of G protein-coupled receptor activation. Annu Rev Biochem. (2018) 87:897-919. doi: 10.1146/annurev-biochem-060614-033910

9. Boularan C, Kehrl JH. Implications of non-canonical G-protein signaling for the immune system. Cell Signal. (2014) 26:1269-82. doi: $10.1016 /$ j.cellsig.2014.02.010

10. Couvineau A, Laburthe M. VPAC receptors: structure, molecular pharmacology and interaction with accessory proteins. $\mathrm{Br} J$ Pharmacol. (2012) 166:42-50. doi: 10.1111/j.1476-5381.2011.01676.x

11. Sun $\mathrm{L}, \mathrm{Ye} \mathrm{RD}$. Role of $\mathrm{G}$ protein-coupled receptors in inflammation. Acta Pharmacol Sin. (2012) 33:342-50. doi: 10.1038/aps.2011.200

12. Lammermann $T$, Kastenmuller W. Concepts of GPCR-controlled navigation in the immune system. Immunol Rev. (2019) 289:205-231. doi: 10.1111/imr.12752

13. Veldhuis NA, Poole DP, Grace M, McIntyre P, Bunnett NW. The G proteincoupled receptor-transient receptor potential channel axis: molecular insights for targeting disorders of sensation and inflammation. Pharmacol Rev. (2015) 67:36-73. doi: 10.1124/pr.114.009555

14. Neumann E, Khawaja K, Muller-Ladner U. G protein-coupled receptors in rheumatology. Nat Rev Rheumatol. (2014) 10:429-36. doi: 10.1038/nrrheum.2014.62

15. Polat G, Ugan RA, Cadirci E, Halici Z. Sepsis and septic shock: current treatment strategies and new approaches. Eur J Med. (2017) 49:53-8. doi: 10.5152/eurasianjmed.2017.17062

16. El-Salhy M, Solomon T, Hausken T, Gilja OH, Hatlebakk JG. Gastrointestinal neuroendocrine peptides/amines in inflammatory bowel disease. World $J$ Gastroenterol. (2017) 23:5068-85. doi: 10.3748/wjg.v23.i28.5068

17. Pabreja K, Mohd MA, Koole C, Wootten D, Furness SG. Molecular mechanisms underlying physiological and receptor pleiotropic effects

\section{FUNDING}

Our work on orexins was supported in part by Inserm Transfert, and co-supported by European Union and Région Normandie. Europe gets involved in Normandie with European Regional Development Fund (ERDF). This work was also supported by INSERM U1149/The Inflammation Research Center (CRI), the Institut National du Cancer (INCA) [grant number $\mathrm{N}^{\circ} 2013-213$ ] and the Ligue Contre le Cancer [grant numbers $\mathrm{R} 16020 \mathrm{HH}$, GB/MA/CD/EP-12062].

mediated by GLP-1R activation. Br J Pharmacol. (2014) 171:1114-28. doi: $10.1111 /$ bph. 12313

18. Du C, Xie X. G protein-coupled receptors as therapeutic targets for multiple sclerosis. Cell Res. (2012) 22:1108-28. doi: 10.1038/cr.2012.87

19. Nayak AP, Deshpande DA, Penn RB. New targets for resolution of airway remodeling in obstructive lung diseases. F1000Res. (2018) 7:F1000. doi: 10.12688/f1000research.14581.1

20. Simoes e Silva AC, Silveira KD, Ferreira AJ, Teixeira MM. ACE2, angiotensin-(1-7) and Mas receptor axis in inflammation and fibrosis. $\mathrm{Br} \mathrm{J}$ Pharmacol. (2013) 169:477-92. doi: 10.1111/bph.12159

21. Riddy DM, Delerive P, Summers RJ, Sexton PM, Langmead CJ. G protein-coupled receptors targeting insulin resistance, obesity, and type 2 diabetes mellitus. Pharmacol Rev. (2018) 70:39-67. doi: 10.1124/pr.117. 014373

22. Couvineau A, Dayot S, Nicole P, Gratio V, Rebours V, Couvelard A, Voisin T. The anti-tumoral properties of Orexin/Hypocretin hypothalamic neuropeptides: an unexpected therapeutic role. Front Endocrinol. (2018) 9:573. doi: $10.3389 /$ fendo. 2018.00573

23. Tsujino N, Sakurai T. Orexin/hypocretin: a neuropeptide at the interface of sleep, energy homeostasis, and reward system. Pharmacol Rev. (2009) 61:162-76. doi: 10.1124/pr.109.001321

24. de Lecea L, Kilduff TS, Peyron C, Gao X, Foye PE, Danielson PE, et al. The hypocretins: hypothalamus-specific peptides with neuroexcitatory activity. Proc Natl Acad Sci USA. (1998) 95:322-7. doi: 10.1073/pnas.95.1.322

25. Sakurai T, Amemiya A, Ishii M, Matsuzaki I, Chemelli RM, Tanaka H, et al. Orexins and orexin receptors: a family of hypothalamic neuropeptides and $\mathrm{G}$ protein-coupled receptors that regulate feeding behavior. Cell. (1998) 92:696. doi: 10.1016/S0092-8674(00)80949-6

26. Kukkonen JP. Orexin/hypocretin signaling. Curr Top Behav Neurosci. (2017) 33:17-50. doi: 10.1007/7854_2016_49

27. Mieda M, Yanagisawa M. Sleep, feeding, and neuropeptides: roles of orexins and orexin receptors. Curr Opin Neurobiol. (2002) 12:339-45. doi: 10.1016/S0959-4388(02)00331-8

28. Chemelli RM, Willie JT, Sinton CM, Elmquist JK, Scammell T, Lee C, et al. Narcolepsy in orexin knockout mice: molecular genetics of sleep regulation. Cell. (1999) 98:437-51. doi: 10.1016/S0092-8674(00)81973-X

29. Lin L, Faraco J, Li R, Kadotani H, Rogers W, Lin X, et al. The sleep disorder canine narcolepsy is caused by a mutation in the hypocretin (orexin) receptor 2 gene. Cell. (1999) 98:365-76. doi: 10.1016/S0092-8674(00)81965-0

30. Winrow CJ, Renger JJ. Discovery and development of orexin receptor antagonists as therapeutics for insomnia. Br J Pharmacol. (2014) 171:283-93. doi: $10.1111 /$ bph.12261

31. Roecker AJ, Cox CD, Coleman PJ. Orexin receptor antagonists: new therapeutic agents for the treatment of insomnia. J Med Chem. (2016) 59:504-30. doi: 10.1021/acs.jmedchem.5b00832

32. Bonaventure P, Shelton J, Yun S, Nepomuceno D, Sutton S, Aluisio L, et al. Characterization of JNJ-42847922, a Selective Orexin-2 receptor antagonist, as a clinical candidate for the treatment of insomnia. J Pharmacol Exp Ther. (2015) 354:471-82. doi: 10.1124/jpet.115.225466

33. Bonaventure P, Yun S, Johnson PL, Shekhar A, Fitz SD, Shireman BT, et al. A selective orexin-1 receptor antagonist attenuates stress-induced hyperarousal without hypnotic effects. J Pharmacol Exp Ther. (2015) 352:590-601. doi: $10.1124 /$ jpet.114.220392 
34. Cox CD, Breslin MJ, Whitman DB, Schreier JD, McGaughey GB, Bogusky $\mathrm{MJ}$, et al. Discovery of the dual orexin receptor antagonist [(7R)-4-(5-chloro1,3-benzoxazol-2-yl)-7-methyl-1,4-diazepan-1-yl][5-methyl-2-(2H-1,2,3triazol-2-yl)phenyl]methanone (MK-4305) for the treatment of insomnia. $J$ Med Chem. (2010) 53:5320-32. doi: 10.1021/jm100541c

35. Peyron C, Tighe DK, van den Pol AN, de Lecea L, Heller HC, Sutcliffe JG, et al. Neurons containing hypocretin (orexin) project to multiple neuronal systems. J Neurosci. (1998) 18:9996-10015. doi: 10.1523/JNEUROSCI.18-23-09996.1998

36. Thorpe AJ, Cleary JP, Levine AS, Kotz CM. Centrally administered orexin A increases motivation for sweet pellets in rats. Psychopharmacology. (2005) 182:75-83. doi: 10.1007/s00213-005-0040-5

37. Deadwyler SA, Porrino L, Siegel JM, Hampson RE. Systemic and nasal delivery of orexin-A (Hypocretin-1) reduces the effects of sleep deprivation on cognitive performance in nonhuman primates. J Neurosci. (2007) 27:14239-47. doi: 10.1523/JNEUROSCI.3878-07.2007

38. Sharf R, Sarhan M, Brayton CE, Guarnieri DJ, Taylor JR, DiLeone RJ. Orexin signaling via the orexin 1 receptor mediates operant responding for food reinforcement. Biol Psychiatry. (2010) 67:753-60. doi: 10.1016/j.biopsych.2009.12.035

39. Rolls A, Colas D, Adamantidis A, Carter M, Lanre-Amos T, Heller HC, de Lecea L. Optogenetic disruption of sleep continuity impairs memory consolidation. Proc Natl Acad Sci USA. (2011) 108:13305-10. doi: $10.1073 /$ pnas. 1015633108

40. Sears RM, Fink AE, Wigestrand MB, Farb CR, de Lecea L, Ledoux JE. Orexin/hypocretin system modulates amygdala-dependent threat learning through the locus coeruleus. Proc Natl Acad Sci USA. (2013) 110:20260-5. doi: 10.1073/pnas.1320325110

41. Kang JE, Lim MM, Bateman RJ, Lee JJ, Smyth LP, Cirrito JR, et al. Amyloidbeta dynamics are regulated by orexin and the sleep-wake cycle. Science. (2009) 326:1005-7. doi: 10.1126/science.1180962

42. Yang L, Zou B, Xiong X, Pascual C, Xie J, Malik A, et al. Hypocretin/orexin neurons contribute to hippocampus-dependent social memory and synaptic plasticity in mice. J Neurosci. (2013) 33:5275-84. doi: 10.1523/JNEUROSCI.3200-12.2013

43. Butterick TA, Billington CJ, Kotz CM, Nixon JP. Orexin: pathways to obesity resistance? Rev Endocr Metab Disord. (2013) 14:357-64. doi: 10.1007/s11154-013-9259-3

44. Roh JH, Jiang H, Finn MB, Stewart FR, Mahan TE, Cirrito JR, et al. Potential role of orexin and sleep modulation in the pathogenesis of Alzheimer's disease. J Exp Med. (2014) 211:2487-96. doi: 10.1084/jem.20141788

45. Mavanji V, Butterick TA, Duffy CM, Nixon JP, Billington CJ, Kotz CM. Orexin/hypocretin treatment restores hippocampal-dependent memory in orexin-deficient mice. Neurobiol Learn Mem. (2017) 146:21-30. doi: 10.1016/j.nlm.2017.10.014

46. Yuan LB, Dong HL, Zhang HP, Zhao RN, Gong G, Chen XM, et al. Neuroprotective effect of orexin-A is mediated by an increase of hypoxiainducible factor-1 activity in rat. Anesthesiology. (2011) 114:340-54. doi: 10.1097/ALN.0b013e318206ff6f

47. Butterick TA, Nixon JP, Billington CJ, Kotz CM. Orexin A decreases lipid peroxidation and apoptosis in a novel hypothalamic cell model. Neurosci Lett. (2012) 524:30-4. doi: 10.1016/j.neulet.2012.07.002

48. Boss C, Roch C. Orexin research: patent news from 2016. Expert Opin Ther Pathol. (2017) 27:1123-33. doi: 10.1080/13543776.2017.1344221

49. Graybill NL, Weissig V. A review of orexin's unprecedented potential as a novel, highly-specific treatment for various localized and metastatic cancers. SAGE Open Med. (2017) 5:2050312117735774. doi: 10.1177/2050312117735774

50. Xu TR, Yang Y, Ward R, Gao L, Liu Y. Orexin receptors: multi-functional therapeutic targets for sleeping disorders, eating disorders, drug addiction, cancers and other physiological disorders. Cell Signal. (2013) 25:2413-23. doi: 10.1016/j.cellsig.2013.07.025

51. Randeva HS, Karteris E, Grammatopoulos D, Hillhouse EW. Expression of orexin-A and functional orexin type 2 receptors in the human adult adrenals: implications for adrenal function and energy homeostasis. J Clin Endocrinol Metab. (2001) 86:4808-13. doi: 10.1210/jcem.86.10.7921
52. Nakabayashi M, Suzuki T, Takahashi K, Totsune K, Muramatsu Y, Kaneko C, et al. Orexin-A expression in human peripheral tissues. Mol Cell Endocrinol. (2003) 205:43-50. doi: 10.1016/S0303-7207(03)00206-5

53. Kirchgessner AL, Liu M. Orexin synthesis and response in the gut. Neuron. (1999) 24:941-51. doi: 10.1016/S0896-6273(00)81041-7

54. Liguori G, Tafuri S, Miyoshi C, Yanagisawa M, Squillacioti C, De Pasquale V, et al. Localization of orexin $\mathrm{B}$ and orexin-2 receptor in the rat epididymis. Acta Histochem. (2018) 120:292-7. doi: 10.1016/j.acthis.2018.02.011

55. Liguori G, Pavone LM, Assisi L, Langella E, Tafuri S, Mirabella N, et al. Expression of orexin B and its receptor 2 in rat testis. Gen Comp Endocrinol. (2017) 242:66-73. doi: 10.1016/j.ygcen.2015.11.015

56. Valiante S, Liguori G, Tafuri S, Pavone LM, Campese R, Monaco $\mathrm{R}$, et al. Expression and potential role of the peptide orexin-A in prostate cancer. Biochem Biophys Res Commun. (2015) 464:1290-6. doi: 10.1016/j.bbrc.2015.07.124

57. Leonard CS, Kukkonen JP. Orexin/hypocretin receptor signalling: a functional perspective. Br J Pharmacol. (2014) 171:294-313. doi: 10.1111/bph.12296

58. Arihara Z, Takahashi K, Murakami O, Totsune K, Sone M, Satoh F, et al. Immunoreactive orexin-A in human plasma. Peptides. (2001) 22:139-42. doi: 10.1016/S0196-9781(00)00369-7

59. Sakurai S, Nishijima T, Takahashi S, Yamauchi K, Arihara Z, Takahashi K. Clinical significance of daytime plasma orexin-A-like immunoreactivity concentrations in patients with obstructive sleep apnea hypopnea syndrome. Respiration. (2004) 71:380-4. doi: 10.1159/000079643

60. Nicole P, Couvineau P, Jamin N, Voisin T, Couvineau A. Crucial role of the orexin-B C-terminus in the induction of OX1 receptor-mediated apoptosis: analysis by alanine scanning, molecular modelling and site-directed mutagenesis. Br J Pharmacol. (2015) 172:5211-23. doi: 10.1111/bph.13287

61. Sokolowska P, Urbanska A, Namiecinska M, Bieganska K, Zawilska JB. Orexins promote survival of rat cortical neurons. Neurosci Lett. (2012) 506:303-6. doi: 10.1016/j.neulet.2011.11.028

62. Xiong X, White RE, Xu L, Yang L, Sun X, Zou B, et al. Mitigation of murine focal cerebral ischemia by the hypocretin/orexin system is associated with reduced inflammation. Stroke. (2013) 44:764-70. doi: 10.1161/STROKEAHA.112.681700

63. Duffy CM, Hofmeister JJ, Nixon JP, Butterick TA. High fat diet increases cognitive decline and neuroinflammation in a model of orexin loss. Neurobiol Learn Mem. (2019) 157:41-47. doi: 10.1016/j.nlm.2018.11.008

64. Mihara Y, Dohi K, Yofu S, Nakamachi T, Ohtaki H, Shioda S, et al. Expression and localization of the orexin-1 receptor (OX1R) after traumatic brain injury in mice. J Mol Neurosci. (2011) 43:162-8. doi: 10.1007/s12031-010-9438-6

65. Nakamachi T, Endo S, Ohtaki H, Yin L, Kenji D, Kudo Y, et al. Orexin1 receptor expression after global ischemia in mice. Regul Pept. (2005) 126:49-54. doi: 10.1016/j.regpep.2004.08.037

66. Duffy CM, Yuan C, Wisdorf LE, Billington CJ, Kotz CM, Nixon JP, et al. Role of orexin A signaling in dietary palmitic acid-activated microglial cells. Neurosci Lett. (2015) 606:140-4. doi: 10.1016/j.neulet.2015.08.033

67. Hu X, Li P, Guo Y, Wang H, Leak RK, Chen S, et al. Microglia/macrophage polarization dynamics reveal novel mechanism of injury expansion after focal cerebral ischemia. Stroke. (2012) 43:3063-70. doi: 10.1161/STROKEAHA.112.659656

68. Perry VH, Holmes C. Microglial priming in neurodegenerative disease. Nat Rev Neurol. (2014) 10:217-24. doi: 10.1038/nrneurol.2014.38

69. Harada S, Fujita-Hamabe W, Tokuyama S. Effect of orexin-A on postischemic glucose intolerance and neuronal damage. J Pharmacol Sci. (2011) 115:155-63. doi: 10.1254/jphs.10264FP

70. Sokolowska P, Urbanska A, Bieganska K, Wagner W, Ciszewski W, Namiecinska M, et al. Orexins protect neuronal cell cultures against hypoxic stress: an involvement of Akt signaling. J Mol Neurosci. (2014) 52:48-55. doi: 10.1007/s12031-013-0165-7

71. Esmaeili-Mahani S, Vazifekhah S, Pasban-Aliabadi H, Abbasnejad M, Sheibani V. Protective effect of orexin-A on 6-hydroxydopamineinduced neurotoxicity in SH-SY5Y human dopaminergic neuroblastoma cells. Neurochem Int. (2013) 63:719-25. doi: 10.1016/j.neuint.2013. 09.022 
72. Feng Y, Liu T, Li XQ, Liu Y, Zhu XY, Jankovic J, et al. Neuroprotection by Orexin-A via HIF-1alpha induction in a cellular model of Parkinson's disease. Neurosci Lett. (2014) 579:35-40. doi: 10.1016/j.neulet.2014.07.014

73. Pasban-Aliabadi H, Esmaeili-Mahani S, Abbasnejad M. Orexin-A protects human neuroblastoma SH-SY5Y cells against 6-hydroxydopamineinduced neurotoxicity: involvement of PKC and PI3K signaling pathways. Rejuvenation Res. (2017) 20:125-33. doi: 10.1089/rej.2016.1836

74. Davies J, Chen J, Pink R, Carter D, Saunders N, Sotiriadis G, et al. Orexin receptors exert a neuroprotective effect in Alzheimer's disease (AD) via heterodimerization with GPR103. Sci Rep. (2015) 5:12584. doi: $10.1038 /$ srep 12584

75. Bulbul M, Tan R, Gemici B, Ongut G, Izgut-Uysal VN. Effect of orexin-a on ischemia-reperfusion-induced gastric damage in rats. J Gastroenterol. (2008) 43:202-7. doi: 10.1007/s00535-007-2148-3

76. Kitamura E, Hamada J, Kanazawa N, Yonekura J, Masuda R, Sakai F, et al. The effect of orexin-A on the pathological mechanism in the rat focal cerebral ischemia. Neurosci Res. (2010) 68:154-7. doi: 10.1016/j.neures.2010.06.010

77. Ogawa Y, Irukayama-Tomobe Y, Murakoshi N, Kiyama M, Ishikawa Y, Hosokawa N, et al. Peripherally administered orexin improves survival of mice with endotoxin shock. Elife. (2016) 5:e21055. doi: 10.7554/eLife.21055

78. Grossberg AJ, Zhu X, Leinninger GM, Levasseur PR, Braun TP, Myers MG Jr, et al. Inflammation-induced lethargy is mediated by suppression of orexin neuron activity. J Neurosci. (2011) 31:11376-86. doi: 10.1523/JNEUROSCI.2311-11.2011

79. Becquet L, Abad C, Leclercq M, Miel C, Jean L, Riou G, et al. Systemic administration of orexin A ameliorates established experimental autoimmune encephalomyelitis by diminishing neuroinflammation. J Neuroinflammation. (2019) 16:64. doi: 10.1186/s12974-019-1447-y

80. Messal N, Fernandez N, Dayot S, Gratio V, Nicole P, Prochasson C, et al. Ectopic expression of OX1R in ulcerative colitis mediates anti-inflammatory effect of orexin-A. Biochim Biophys Acta Mol Basis Dis. (2018) 1864:3618-28. doi: 10.1016/j.bbadis.2018.08.023

81. Dauvilliers Y, Arnulf I, Mignot E. Narcolepsy with cataplexy. Lancet. (2007) 369:499-511. doi: 10.1016/S0140-6736(07)60237-2

82. Peyron C, Faraco J, Rogers W, Ripley B, Overeem S, Charnay Y, et al. A mutation in a case of early onset narcolepsy and a generalized absence of hypocretin peptides in human narcoleptic brains. Nat Med. (2000) 6:991-7. doi: $10.1038 / 79690$

83. Thannickal TC, Moore RY, Nienhuis R, Ramanathan L, Gulyani S, Aldrich $\mathrm{M}$, et al. Reduced number of hypocretin neurons in human narcolepsy. Neuron. (2000) 27:469-74. doi: 10.1016/S0896-6273(00)00058-1

84. Tafti M, Hor H, Dauvilliers Y, Lammers GJ, Overeem S, Mayer G, et al. DQB1 locus alone explains most of the risk and protection in narcolepsy with cataplexy in Europe. Sleep. (2014) 37:19-25. doi: 10.5665/sleep.3300

85. Tafti M, Lammers GJ, Dauvilliers Y, Overeem S, Mayer G, Nowak J, et al. Narcolepsy-associated HLA class I alleles implicate cell-mediated cytotoxicity. Sleep. (2016) 39:581-7. doi: 10.5665/sleep.5532

86. Ollila HM, Ravel JM, Han F, Faraco J, Lin L, Zheng X, et al. HLA-DPB1 and HLA class I confer risk of and protection from narcolepsy. Am J Hum Genet. (2015) 96:136-46. doi: 10.1016/j.ajhg.2014.12.010

87. Hallmayer J, Faraco J, Lin L, Hesselson S, Winkelmann J, Kawashima M, et al. Narcolepsy is strongly associated with the T-cell receptor alpha locus. Nat Genet. (2009) 41:708-11. doi: 10.1038/ng.372

88. Han F, Faraco J, Dong XS, Ollila HM, Lin L, Li J, et al. Genome wide analysis of narcolepsy in China implicates novel immune loci and reveals changes in association prior to versus after the $2009 \mathrm{H} 1 \mathrm{~N} 1$ influenza pandemic. PLoS Genet. (2013) 9:e1003880. doi: 10.1371/journal.pgen.1003880

89. Cvetkovic-Lopes V, Bayer L, Dorsaz S, Maret S, Pradervand S, Dauvilliers $\mathrm{Y}$, et al. Elevated tribbles homolog 2-specific antibody levels in narcolepsy patients. J Clin Invest. (2010) 120:713-9. doi: 10.1172/JCI41366

90. Bergman P, Adori C, Vas S, Kai-Larsen Y, Sarkanen T, Cederlund A, et al. Narcolepsy patients have antibodies that stain distinct cell populations in rat brain and influence sleep patterns. Proc Natl Acad Sci USA. (2014) 111:E3735-44. doi: 10.1073/pnas.1412189111

91. Ahmed SS, Volkmuth W, Duca J, Corti L, Pallaoro M, Pezzicoli A, et al. Antibodies to influenza nucleoprotein cross-react with human hypocretin receptor 2. Sci Transl Med. (2015) 7:294ra105. doi: $10.1126 /$ scitranslmed.aab2354
92. Dauvilliers Y, Arnulf I, Lecendreux M, Monaca Charley C, Franco P, Drouot $\mathrm{X}$, et al. Increased risk of narcolepsy in children and adults after pandemic H1N1 vaccination in France. Brain. (2013) 136:2486-96. doi: 10.1093/brain/awt187

93. Szakacs A, Darin N, Hallbook T. Increased childhood incidence of narcolepsy in western Sweden after H1N1 influenza vaccination. Neurology. (2013) 80:1315-21. doi: 10.1212/WNL.0b013e31828ab26f

94. Nohynek H, Jokinen J, Partinen M, Vaarala O, Kirjavainen T, Sundman J, et al. AS03 adjuvanted AH1N1 vaccine associated with an abrupt increase in the incidence of childhood narcolepsy in Finland. PLoS ONE. (2012) 7:e33536. doi: 10.1371/journal.pone.0033536

95. Han F, Lin L, Li J, Dong XS, Mignot E. Decreased incidence of childhood narcolepsy 2 years after the 2009 H1N1 winter flu pandemic. Ann Neurol. (2013) 73:560. doi: 10.1002/ana.23799

96. Bernard-Valnet R, Yshii L, Queriault C, Nguyen XH, Arthaud S, Rodrigues $\mathrm{M}$, et al. CD8 T cell-mediated killing of orexinergic neurons induces a narcolepsy-like phenotype in mice. Proc Natl Acad Sci USA. (2016) 113:10956-61. doi: 10.1073/pnas.1603325113

97. Willie JT, Chemelli RM, Sinton CM, Tokita S, Williams SC, Kisanuki YY, et al. Distinct narcolepsy syndromes in Orexin receptor-2 and Orexin null mice: molecular genetic dissection of Non-REM and REM sleep regulatory processes. Neuron. (2003) 38:715-30. doi: 10.1016/S0896-6273(03)0 0330-1

98. Hondo M, Nagai K, Ohno K, Kisanuki Y, Willie JT, Watanabe T, et al. Histamine-1 receptor is not required as a downstream effector of orexin2 receptor in maintenance of basal sleep/wake states. Acta Physiol. (2010) 198:287-94. doi: 10.1111/j.1748-1716.2009.02032.x

99. Dugovic C, Shelton JE, Yun S, Bonaventure P, Shireman BT, Lovenberg TW. Orexin-1 receptor blockade dysregulates REM sleep in the presence of orexin-2 receptor antagonism. Front Neurosci. (2014) 8:28. doi: 10.3389/fnins.2014.00028

100. Irukayama-Tomobe $\mathrm{Y}$, Ogawa $\mathrm{Y}$, Tominaga H, Ishikawa $\mathrm{Y}$, Hosokawa N, Ambai S, et al. Nonpeptide orexin type-2 receptor agonist ameliorates narcolepsy-cataplexy symptoms in mouse models. Proc Natl Acad Sci USA. (2017) 114:5731-6. doi: 10.1073/pnas.1700499114

101. Zhang X, Dong F, Ren J, Driscoll MJ, Culver B. High dietary fat induces NADPH oxidase-associated oxidative stress and inflammation in rat cerebral cortex. Exp Neurol. (2005) 191:318-25. doi: 10.1016/j.expneurol.2004. 10.011

102. Pipatpiboon N, Pratchayasakul W, Chattipakorn N, Chattipakorn SC. PPARgamma agonist improves neuronal insulin receptor function in hippocampus and brain mitochondria function in rats with insulin resistance induced by long term high-fat diets. Endocrinology. (2012) 153:329-38. doi: 10.1210/en.2011-1502

103. Thaler JP, Yi CX, Schur EA, Guyenet SJ, Hwang BH, Dietrich MO, et al. Obesity is associated with hypothalamic injury in rodents and humans. J Clin Invest. (2012) 122:153-62. doi: 10.1172/JCI59660

104. Cai D, Neuroinflammation in overnutrition-induced diseases. Vitam Horm. (2013) 91:195-218. doi: 10.1016/B978-0-12-407766-9.00008-0

105. Pipatpiboon N, Pintana H, Pratchayasakul W, Chattipakorn N, Chattipakorn SC. DPP4-inhibitor improves neuronal insulin receptor function, brain mitochondrial function and cognitive function in rats with insulin resistance induced by high-fat diet consumption. Eur J Neurosci. (2013) 37:839-49. doi: 10.1111/ejn.12088

106. Pugazhenthi S, Nesterova A, Jambal P, Audesirk G, Kern M, Cabell L, et al. Oxidative stress-mediated down-regulation of bcl-2 promoter in hippocampal neurons. J Neurochem. (2003) 84:982-96. doi: 10.1046/j.1471-4159.2003.01606.x

107. Moraes JC, Coope A, Morari J, Cintra DE, Roman EA, Pauli JR, et al. High-fat diet induces apoptosis of hypothalamic neurons. PLoS ONE. (2009) 4:e5045. doi: 10.1371/journal.pone.0005045

108. Wang Z, Liu D, Wang F, Liu S, Zhao S, Ling EA, Hao A. Saturated fatty acids activate microglia via Toll-like receptor 4/NF- $\mathrm{B}$ signalling. Br J Nutr. (2012) 107:229-41. doi: 10.1017/S0007114511002868

109. Valdearcos M, Robblee MM, Benjamin DI, Nomura DK, Xu AW, Koliwad SK. Microglia dictate the impact of saturated fat consumption on hypothalamic inflammation and neuronal function. Cell Rep. (2014) 9:2124-38. doi: 10.1016/j.celrep.2014.11.018 
110. Duffy CM, Nixon JP, Butterick TA. Orexin A attenuates palmitic acidinduced hypothalamic cell death. Mol Cell Neurosci. (2016) 75:93-100. doi: 10.1016/j.mcn.2016.07.003

111. Selkoe DJ. Alzheimer's disease results from the cerebral accumulation and cytotoxicity of amyloid beta-protein. J Alzheimers Dis. (2001) 3:75-80. doi: 10.3233/JAD-2001-3111

112. Eikelenboom P, Veerhuis R, Scheper W, Rozemuller AJ, van Gool WA, Hoozemans JJ. The significance of neuroinflammation in understanding Alzheimer's disease. J Neural Transm. (2006) 113:1685-95. doi: 10.1007/s00702-006-0575-6

113. Minter MR, Taylor JM, Crack PJ. The contribution of neuroinflammation to amyloid toxicity in Alzheimer's disease. J Neurochem. (2016) 136:457-74. doi: $10.1111 /$ jnc. 13411

114. Xie L, Kang H, Xu Q, Chen MJ, Liao Y, Thiyagarajan M, et al. Sleep drives metabolite clearance from the adult brain. Science. (2013) 342:373-7. doi: 10.1126/science.1241224

115. Tononi G. Slow wave homeostasis and synaptic plasticity. J Clin Sleep Med. (2009) 5:S16-9.

116. Vyazovskiy VV, Faraguna U. Sleep and synaptic homeostasis. Curr Top Behav Neurosci. (2015) 25:91-121. doi: 10.1007/7854_2014_301

117. Carroll JE, Cole SW, Seeman TE, Breen EC, Witarama T, Arevalo JM, et al. Partial sleep deprivation activates the DNA damage response (DDR) and the senescence-associated secretory phenotype (SASP) in aged adult humans. Brain Behav Immun. (2016) 51:223-9. doi: 10.1016/j.bbi.2015.08.024

118. Prinz PN, Vitaliano PP, Vitiello MV, Bokan J, Raskind M, Peskind E, et al. Sleep, EEG and mental function changes in senile dementia of the Alzheimer's type. Neurobiol Aging. (1982) 3:361-70. doi: 10.1016/0197-4580(82)90024-0

119. Bliwise DL. Sleep disorders in Alzheimer's disease and other dementias. Clin Cornerstone. (2004) 6 (Suppl. 1):S16-28. doi: 10.1016/S1098-3597(04)90014-2

120. Walker MP, Stickgold R. Sleep, memory, and plasticity. Annu Rev Psychol. (2006) 57:139-66. doi: 10.1146/annurev.psych.56.091103.070307

121. Bliwise DL, Mercaldo ND, Avidan AY, Boeve BF, Greer SA, Kukull WA. Sleep disturbance in dementia with Lewy bodies and Alzheimer's disease: a multicenter analysis. Dement Geriatr Cogn Disord. (2011) 31:239-46. doi: $10.1159 / 000326238$

122. Duncan MJ, Farlow H, Tirumalaraju C, Yun DH, Wang C, Howard JA, et al. Effects of the dual orexin receptor antagonist DORA-22 on sleep in 5XFAD mice. Alzheimers Dement. (2019) 5:70-80. doi: 10.1016/j.trci.2019.01.003

123. Dendrou CA, Fugger L. Immunomodulation in multiple sclerosis: promises and pitfalls. Curr Opin Immunol. (2017) 49:37-43. doi: 10.1016/j.coi.2017.08.013

124. Zadeh R, Askari M, Azadani NN, Ataei A, Ghadimi K, Tavoosi N, et al. Mechanism and adverse effects of multiple sclerosis drugs: a review article. Part 1. Int J Physiol Pathophysiol Pharmacol. (2019) 11:95-104.

125. Zadeh R, Ghadimi K, Ataei A, Askari M, Sheikhinia N, Tavoosi N, et al. Mechanism and adverse effects of multiple sclerosis drugs: a review article. Part 2. Int J Physiol Pathophysiol Pharmacol. (2019) 11:105-114.

126. Fatemi I, Shamsizadeh A, Roohbakhsh A, Ayoobi F, Sanati MH, Motevalian $\mathrm{M}$. Increase in mRNA level of orexin 1 and 2 receptors following induction of experimental autoimmune encephalomyelitis in mice. Iran J Allergy Asthma Immunol. (2016) 15:20-6.

127. Fatemi I, Shamsizadeh A, Ayoobi F, Taghipour Z, Sanati MH, Roohbakhsh A, et al. Role of orexin-A in experimental autoimmune encephalomyelitis. J Neuroimmunol. (2016) 291:101-9. doi: 10.1016/j.jneuroim.2016. 01.001

128. Kastin AJ, Akerstrom V. Orexin A but not orexin B rapidly enters brain from blood by simple diffusion. J Pharmacol Exp Ther. (1999) 289:219-23.

129. Oligschlaeger Y, Yadati T, Houben T, Condello Olivan CM, Shiri-Sverdlov R. Inflammatory bowel disease: a stressed “Gut/Feeling”. Cells. (2019) 8:E659. doi: $10.3390 /$ cells 8070659

130. Danese S, Fiocchi C. Ulcerative colitis. N Engl J Med. (2011) 365:1713-25. doi: 10.1056/NEJMra1102942

131. Domenech E, Manosa M, Cabre E. An overview of the natural history of inflammatory bowel diseases. Dig Dis. (2014) 32:320-7. doi: $10.1159 / 000358131$
132. Ng SC, Shi HY, Hamidi N, Underwood FE, Tang W, Benchimol EI, et al. Worldwide incidence and prevalence of inflammatory bowel disease in the 21st century: a systematic review of population-based studies. Lancet. (2018) 390:2769-78. doi: 10.1016/S0140-6736(17)32448-0

133. de Souza HS, Fiocchi C. Immunopathogenesis of IBD: current state of the art. Nat Rev Gastroenterol Hepatol. (2016) 13:13-27. doi: 10.1038/nrgastro.2015.186

134. Hindryckx P, Jairath V, D’Haens G. Acute severe ulcerative colitis: from pathophysiology to clinical management. Nat Rev Gastroenterol Hepatol. (2016) 13:654-64. doi: 10.1038/nrgastro.2016.116

135. Thomas S, Baumgart DC. Targeting leukocyte migration and adhesion in Crohn's disease and ulcerative colitis. Inflammopharmacology. (2012) 20:118. doi: 10.1007/s10787-011-0104-6

136. Ashton JC. Cannabinoids for the treatment of inflammation. Curr Opin Investig Drugs. (2007) 8:373-84.

137. Zhang M, Venable JD, Thurmond RL. The histamine $\mathrm{H} 4$ receptor in autoimmune disease. Expert Opin Investig Drugs. (2006) 15:1443-52. doi: 10.1517/13543784.15.11.1443

138. Waschek JA. VIP and PACAP: neuropeptide modulators of CNS inflammation, injury, and repair. Br J Pharmacol. (2013) 169:512-23. doi: 10.1111/bph.12181

139. Voisin T, El Firar A, Fasseu M, Rouyer-Fessard C, Descatoire V, Walker F, et al. Aberrant expression of OX1 receptors for orexins in colon cancers and liver metastases: an openable gate to apoptosis. Cancer Res. (2011) 71:3341-51. doi: 10.1158/0008-5472.CAN-10-3473

140. Zhang D, Ren YB, Wei K, Hong J, Yang YT, Wu LJ, et al. Herb-partitioned moxibustion alleviates colon injuries in ulcerative colitis rats. World $\mathrm{J}$ Gastroenterol. (2018) 24:3384-97. doi: 10.3748/wjg.v24.i30.3384

141. Martinez-Orozco FJ, Vicario JL, Villalibre-Valderrey I, De Andres C, Fernandez-Arquero M, Peraita-Adrados R. Narcolepsy with cataplexy and comorbid immunopathological diseases. J Sleep Res. (2014) 23:414-9. doi: $10.1111 /$ jsr. 12143

142. Tunisi L, Forte N, Fernandez-Rilo AC, Mavaro I, Capasso R, D’Angelo $\mathrm{L}$, et al. Orexin-A prevents lipopolysaccharide-induced neuroinflammation at the level of the intestinal barrier. Front Endocrinol. (2019) 10:219. doi: $10.3389 /$ fendo.2019.00219

143. Dayot S, Speisky D, Couvelard A, Bourgoin P, Gratio V, Cros J, et al. In vitro, in vivo and ex vivo demonstration of the antitumoral role of hypocretin-1/orexin-A and almorexant in pancreatic ductal adenocarcinoma. Oncotarget. (2018) 9:6952-67. doi: 10.18632/oncotarget. 24084

144. Voisin T, El Firar A, Rouyer-Fessard C, Gratio V, Laburthe M. A hallmark of immunoreceptor, the tyrosine-based inhibitory motif ITIM, is present in the $\mathrm{G}$ protein-coupled receptor OX1R for orexins and drives apoptosis: a novel mechanism. FASEB J. (2008) 22:1993-2002. doi: 10.1096/fj.07098723

145. El Firar A, Voisin T, Rouyer-Fessard C, Ostuni MA, Couvineau A, Laburthe M. Discovery of a functional immunoreceptor tyrosine-based switch motif in a 7-transmembrane-spanning receptor: role in the orexin receptor OX1R-driven apoptosis. FASEB J. (2009) 23:4069-80. doi: 10.1096/fj.09131367

146. Dellinger RP, Levy MM, Rhodes A, Annane D, Gerlach H, Opal SM, et al. Surviving sepsis campaign guidelines committee including the pediatric, surviving sepsis campaign: international guidelines for management of severe sepsis and septic shock, 2012. Intensive Care Med. (2013) 39:165-228. doi: $10.1007 / \mathrm{s} 00134-012-2769-8$

147. Hattori Y, Hattori K, Suzuki T, Matsuda N. Recent advances in the pathophysiology and molecular basis of sepsis-associated organ dysfunction: novel therapeutic implications and challenges. Pharmacol Ther. (2017) 177:56-66. doi: 10.1016/j.pharmthera.2017.02.040

148. Rello J, Valenzuela-Sanchez F, Ruiz-Rodriguez M, Moyano S. Sepsis: a review of advances in management. Adv Ther. (2017) 34:2393-2411. doi: 10.1007/s12325-017-0622-8

149. Li X, Su J, Cui X, Li Y, Barochia A, Eichacker PQ. Can we predict the effects of NF-kappaB inhibition in sepsis? Studies with parthenolide and ethyl pyruvate. Expert Opin Investig Drugs. (2009) 18:1047-60. doi: $10.1517 / 13543780903018880$ 
150. Hotchkiss RS, Swanson PE, Cobb JP, Jacobson A, Buchman TG, Karl IE. Apoptosis in lymphoid and parenchymal cells during sepsis: findings in normal and T- and B-cell-deficient mice. Crit Care Med. (1997) 25:1298-307. doi: 10.1097/00003246-19970800000015

151. Cristofaro P, Opal SM. The Toll-like receptors and their role in septic shock. Expert Opin Ther Targets. (2003) 7:603-12. doi: 10.1517/14728222. 7.5.603

152. Aziz M, Jacob A, Yang WL, Matsuda A, Wang P. Current trends in inflammatory and immunomodulatory mediators in sepsis. J Leukoc Biol. (2013) 93:329-42. doi: 10.1189/jlb.0912437

153. Pinheiro da Silva F, Machado MC, Velasco IT. Neuropeptides in sepsis: from brain pathology to systemic inflammation. Peptides. (2013) 44:135-8. doi: 10.1016/j.peptides.2013.03.029

154. Alberelli MA, De Candia E. Functional role of protease activated receptors in vascular biology. Vascul Pharmacol. (2014) 62:72-81. doi: 10.1016/j.vph.2014.06.001

155. Kanashiro A, Sonego F, Ferreira RG, Castanheira FV, Leite CA, Borges VF, et al. Therapeutic potential and limitations of cholinergic antiinflammatory pathway in sepsis. Pharmacol Res. (2017) 117:1-8. doi: 10.1016/j.phrs.2016.12.014

156. Zhang L, Qiu C, Yang L, Zhang Z, Zhang Q, Wang B, et al. GPR18 expression on PMNs as biomarker for outcome in patient with sepsis. Life Sci. (2019) 217:49-56. doi: 10.1016/j.lfs.2018.11.061
157. Seemann S, Zohles F, Lupp A. Comprehensive comparison of three different animal models for systemic inflammation. J Biomed Sci. (2017) 24:60. doi: 10.1186/s12929-017-0370-8

158. Deutschman CS, Raj NR, McGuire EO, Kelz MB. Orexinergic activity modulates altered vital signs and pituitary hormone secretion in experimental sepsis. Crit Care Med. (2013) 41:e368-75. doi: 10.1097/CCM.0b013e31828e9843

159. Hirota K. Sepsis and the orexin system. J Anesth. (2016) 30:919-22. doi: 10.1007/s00540-016-2246-6

160. Takekawa D, Kushikata T, Akaishi M, Nikaido Y, Hirota K. Influence of orexinergic system on survival in septic rats. Neuropsychobiology. (2019) 77:45-8. doi: 10.1159/000493739

Conflict of Interest: The authors declare that the research was conducted in the absence of any commercial or financial relationships that could be construed as a potential conflict of interest.

Copyright (C) 2019 Couvineau, Voisin, Nicole, Gratio, Abad and Tan. This is an open-access article distributed under the terms of the Creative Commons Attribution License (CC BY). The use, distribution or reproduction in other forums is permitted, provided the original author(s) and the copyright owner(s) are credited and that the original publication in this journal is cited, in accordance with accepted academic practice. No use, distribution or reproduction is permitted which does not comply with these terms. 